\title{
EARLY EDUCATION AND CARE
}

Overlap Indicates Need to Assess

Crosscutting

Programs
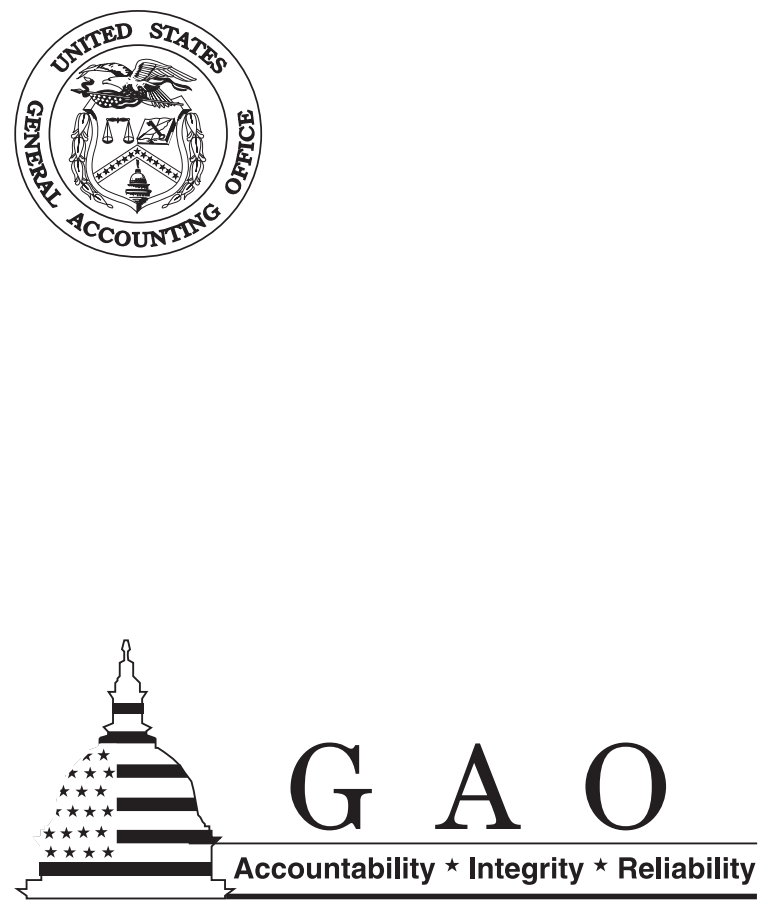



\section{Contents}

Appendix I: Federal Programs That Provided or Supported

Education and Care for Children Under 5 Years of

Age, Fiscal Year 1999

Appendix II: Proportion of Children Receiving Services From Education and Care Programs, by Target Group

Appendix III: Comments From the Department of Education

Appendix IV: Comments From the Department of Health and Human Services

Table 1: Federal Spending on Education and Care of Children Under Age 5, Fiscal Year 1999

Table 2: Estimated Number of Participants Under Age 5 in Fiscal Year 1999, by Program

Table 3: Federal Programs That Provide E ducation and Care to Children Under Age 5, by Target Group

Table 4: Programs Targeting Native American Children-Proportion of Participating Children Under Age 5 Receiving Services

\section{Figures}

Figure 1: Number of Federal Programs That Provide or Support Education and Care for Children Under Age 5, by Department or Agency

Figure 2: Federal Programs With a Program Purpose of Providing Education and Care That Serve Children Under Age 5, by Federal Department and Office 


\section{Contents}

\section{Abbreviations}

BIA Bureau of Indian Affairs

CCDF Child Care Development Fund

Education Department of Education

GPRA Government Performance and Results Act

HHS Department of Health and Human Services

Interior Department of the Interior

SSBG Social Services Block Grant

TANF Temporary Assistance to Needy Families 
April 28, 2000

The Honorable George V. Voinovich

Chairman, Subcommittee on Oversight of

Government Management, Restructuring and

the District of Columbia

Committee on Governmental Affairs

United States Senate

Dear Mr. Chairman:

Over the last two decades, a nationwide emphasis on better preparing children for school, understanding how children learn, and improving the educational and social outcomes for all children has focused attention on early childhood education and care. In response to these issues, a number of federal programs have been created that focus either directly or indirectly on early childhood education and care. In 1999, we testified that the large number of programs creates the potential for inefficient service delivery and difficulty accessing services. ${ }^{1}$ Because of your interest in the early learning experiences of children, you asked us to update our 1994 report on multiple early childhood programs. ${ }^{2}$ Specifically, you asked us to enumerate the federally funded programs that provide education, child care, or services supporting education or child care for children under age 5 , by agency (excluding Department of Defense programs and tax credits) and, for programs that provide education and care as a program purpose, to answer the following questions:

- In fiscal year 1999, what portion of the budget authority for these programs was used for education and care for children under age 5 and how many children in this age group participated in these programs?

- What types of children are these programs targeting and what services are provided to children participating in the programs?

- What information would be needed to assess whether the current array of federal programs is duplicative and what issues should be considered

${ }^{1}$ Results Act: Using Agency Performance Plans to Oversee Early Childhood Programs (GAO/T-HEHS-99-93, Mar. 25, 1999).

${ }^{2}$ Early Childhood Programs: Multiple Programs and Overlapping Target Groups (GAO/HE HS-95-4FS, Oct. 31, 1994). 
in developing options to improve the overall efficiency of federal early childhood education and care programs?

To address your request, we electronically searched the J une 1999 Catalog of F ederal Domestic Assistance using key words associated with early childhood education and care. ${ }^{3}$ We analyzed the Catalog's descriptions of these programs to determine whether they (1) directly fund or support education and/or child care, (2) provide these services to children under age 5, and (3) deliver services in an educational or child care setting. We classified those programs that met all three criteria as early childhood education and care programs.

On the basis of the Catalog's descriptions, we also identified a subset of programs that provided education and care to children under age 5 and whose purpose included education and care. We included Temporary Assistance to Needy Families (TANF) in this subset, although education and care is not a TANF program purpose, because TANF is a significant funding source for child care activities. We contacted agency officials for clarification in a few cases where we could not determine from the Catalog's descriptions whether providing education or child care was a program purpose or whether the program provided services to children under age 5. Using a short questionnaire sent to agency officials, we obtained the following additional information on this subset of programs: fiscal year 1999 budget authority, target population and number of children receiving services, services provided, and the proportion of program participants served who were under age $5 .{ }^{4}$ We did our work in accordance with generally accepted government auditing standards between J uly 1999 and April 2000.

${ }^{3}$ We used the Catalog's federal program number as our unit of analysis when enumerating programs. In some cases the Catalog assigns a single number to a set of related programs. For example, Head Start has a single program number that includes related programs such as Migrant, Native American, and Early Head Start. In other cases, related programs have separate program numbers. For example, Migrant and Indian Even Start programs each have program numbers distinct from the basic Even Start program.

${ }^{4}$ To provide information about the proportion of children under age 5 served, program officials used various data sources, such as discussions with grantees and state officials, monitoring visit reports, performance reports, and anecdotal information. 
Sixty-nine federal programs provided or supported education and care for children under age 5 in fiscal year 1999. Nine different federal agencies and departments administered these programs, though the Departments of Education (Education) and Health and Human Services (HHS) operated most of them. Among the 69 programs, education and care was a program purpose (for example, the Child Care Development F und (CCDF)), an allowable activity (for example, the Native American Employment and Training Program), or was facilitated in some way by the program (for example, the National School Lunch Program). Twenty-nine of these programs, or about 40 percent, provided education and care as a program purpose, but the extent to which they focused on education and care and on children under age 5 varied. For example, Head Start focused almost exclusively on providing education and care for children under age 5, while this was a more minor focus for the Social Services Block Grant (SSBG), where child care was one of many allowable activities. Education administered 22 of the 29 programs, HHS administered 6, and the Department of the Interior (Interior) administered 1.

Spending on early childhood education and care varied widely among the 29 programs. Of the 21 programs that provided data, about half spent a significant proportion of their budget authority, 40 percent or more, on education and care for children under age 5 . The other programs that provided data spent 13 percent or less of their budgets for this purpose. The remaining eight programs could not provide an estimate. Programs spending lesser proportions of their budgets on education and care for children under age 5 spent program funds on other activities or other age groups. The 29 programs spent at least $\$ 9$ billion to provide education and care to children under age 5 in fiscal year 1999. Three HHS programsHead Start, CCDF, and TANF - together accounted for approximately $\$ 8$ billion of the $\$ 9$ billion total.

The 29 programs targeted three major groups of children-the economically disadvantaged, those with special needs, and members of certain native populations. The three largest programs, in terms of spending on children under age 5, targeted the economically disadvantaged. Some of the smaller programs focused on narrower groups, such as children with disabilities. The programs were generally allowed to provide a broad range of services: health, dental, mental health, social, parental, and nutritional services; speech and hearing assessments; and disability screening. Only four programs actually provided most of these services to a high proportion of the participants under age 5 . For the most 
part, the remaining programs provided services to a smaller proportion of participants under age 5 .

When multiple agencies manage multiple early childhood education and care programs, mission fragmentation and program overlap occur. This in turn creates the potential for duplication and service gaps. Though sometimes necessary to meet federal priorities, mission fragmentation and program overlap can create an environment in which programs do not serve participants as efficiently and effectively as possible. To address inefficiencies that may arise under these circumstances, policymakers could choose to coordinate, integrate, or consolidate programs. In order to identify the best method for addressing inefficiencies among fragmented and overlapping programs, policymakers need to know, among other things, whether programs are (1) fulfilling a unique role, (2) unnecessarily redundant, or (3) being administered in the most effective way to meet program as well as federal strategic goals. Information required by the Government Performance and Results Act (GPRA) should provide answers to some of these questions and ultimately help to guide consideration of different options for addressing potential problems among the current configuration of early childhood education and care programs for young children.

\section{Background}

In 1994, GAO reported that the federal government administered more than 90 early childhood programs, of which 34 had education or child care as a primary mission. ${ }^{5}$ These 34 programs delivered a variety of social, health, and educational services and targeted many of them to economically disadvantaged young children. Historically, child care programs and early childhood education programs have existed separately with separate goals. Child care programs, generally administered by HHS, subsidized the cost of child care for low-income parents who were working or engaged in workrelated activities. In contrast, early childhood education programs, generally administered by Education, focused on preparing young children for school. ${ }^{6}$ More recently, the distinction between these two types of programs has blurred as policymakers seek to make educationally enriching care available to young children.

\section{${ }^{5}$ GAO-HEHS-95-4FS.}

${ }^{6}$ Education and Care: Early Childhood Programs and Services for Low-Income Families (GAO/HE HS-00-11, Nov. 15, 1999). 
Our past work has documented both mission fragmentation and program overlap among federal early childhood education and care programs. ${ }^{7}$ Both occur when more than one federal agency (or more than one bureau within an agency) is involved in the same broad area of need. Fragmentation can create inefficient service delivery and administrative complexity because various agencies are administering similar programs serving similar groups of children. In addition, mission fragmentation makes coordination among agencies administering these programs necessary. ${ }^{8}$ Program overlap creates the potential for duplication-which occurs when programs have the same goals, the same activities or strategies to achieve them, or the same targeted recipients. How ever, a certain amount of redundancy among programs may be necessary to improve service delivery, or it may indicate that a certain program is related to a number of areas.

Many Programs Provide or Support Education and Care, but Less Than Half Have This as a Program Purpose
In fiscal year 1999, nine federal agencies or departments administered 69 programs that provided or to some degree supported education and care for children under age 5 . Of these, 29 , or about 40 percent, provided education and care as a program purpose. However, the extent to which these programs focused on education and care and on children under age 5 varied.

\section{Sixty-Nine Federal \\ Programs Provide or Support E ducation and Care for Children Under Age 5}

Nationally, 69 federal programs provided or supported education and care for children under age 5 in fiscal year 1999 (see fig. 1 and app. I). A mong these programs, education and care was a program purpose, or an allowable activity, or the program in some way facilitated the education and care of young children. For example, the purpose of CCDF is to provide child care for children age 0 to 13, and the purpose of the Even Start programs is to provide education and family literacy services to children age 0 to 8 and their parents in low-income families. For some of the programs, providing education and care was an allowable activity. The

${ }^{7}$ See, for example, Managing for Results: Using the Results Act to Address Mission Fragmentation and Program Overlap (GAO/AIMD-97-146, Aug. 29, 1997) and GAO/HE HS-954FS.

${ }^{8}$ Observations on the Department of Education's Fiscal Year 2000 Performance Plan (GAO/HE HS-99-136R, J uly 31, 1999) and GAO/T-HE HS-99-93. 
Native American E mployment and Training Program and TANF - a program designed to help welfare recipients move into the workforce-are allowed to provide child care for working parents. Two Department of Agriculture programs, the National School Lunch Program and the Child and Adult Care Food Program, facilitate education and child care by subsidizing the cost of serving meals to children in child care centers and schools. E ducation administered 34 and HHS administered 13 of the 69 programs.

Twenty-Nine Programs Provide Education and Care as a Program Purpose
Within the group of 69 programs, 29 (about 40 percent) provided education and care as a program purpose and could provide services to children under age 5 (see fig. 2). TANF also fell into this group because it was a significant source of funding for child care. How ever, the extent to which these 29 programs focused on education and care varied. For example, Head Start and Special Education-Grants for Infants and Families with Disabilities focused exclusively on providing education and care for young children. In contrast, SSBG and the bilingual education programs focused in a more minor way on these activities or this age group. In the SSBG program, child care was one of many social services provided; and for the bilingual education programs, preschool was one of several grade levels that could be served. 
Figure 1: Number of Federal Programs That Provide or Support Education and Care for Children Under Age 5, by Department or Agency

Number of Programs

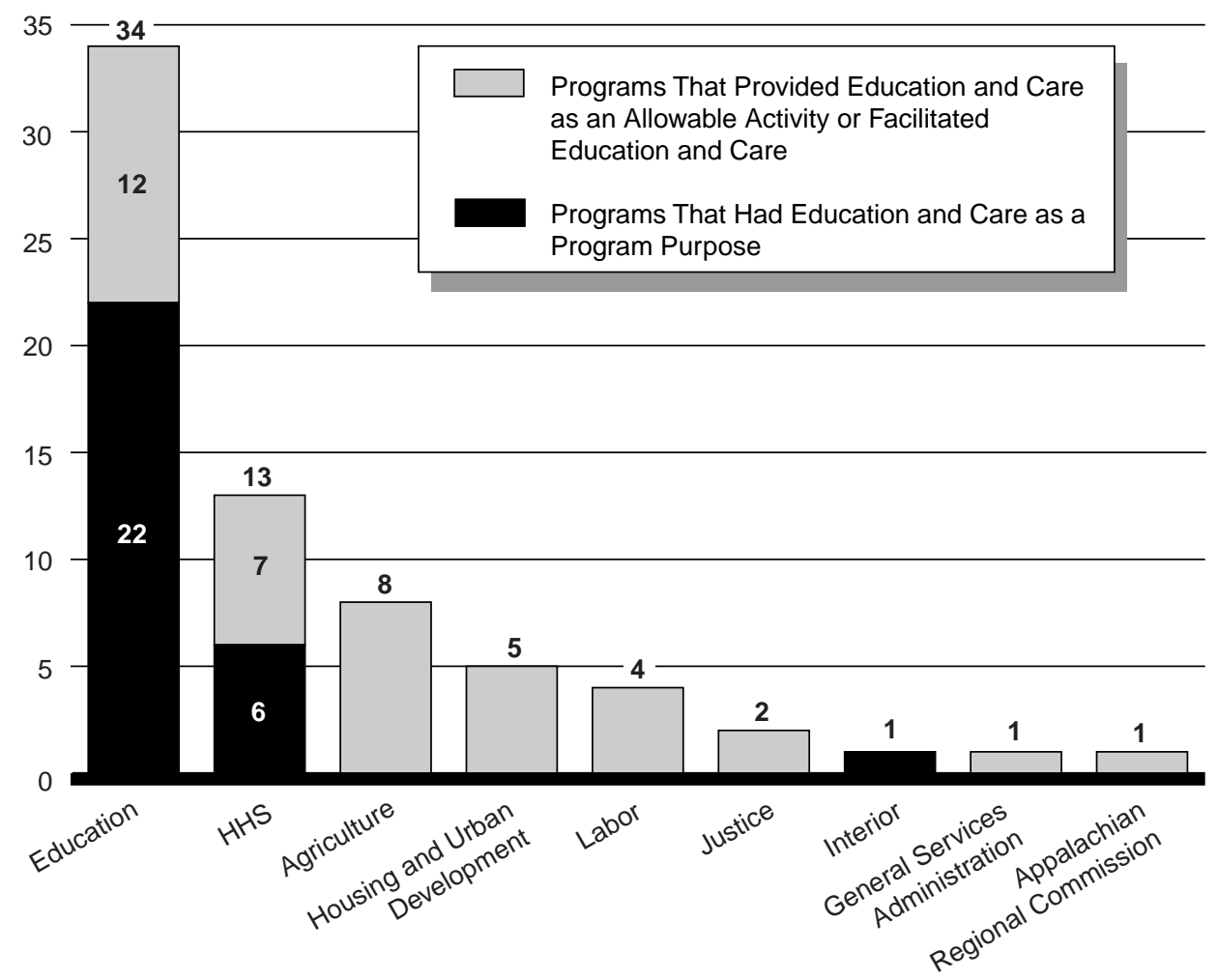

Department 
Programs also differed in how services were delivered and how funds flowed to the programs. For example, under E ducation's Indian E ducationGrants to Local Educational Agencies program, grantees provided educational services directly, whereas CCDF provided vouchers to parents to purchase child care services. HHS provided funds directly to local Head Start grantees, whereas E ducation's Title I program provided grants through state education departments to eligible school districts. ${ }^{9}$ The districts then decided which preschool programs would be funded from their Title I allocation.

Three federal departments administered the 29 programs. In fiscal year 1999 , five offices in E ducation administered 22 programs that, for example, provided educational services to young children and their parents, disabled children, economically disadvantaged children, and children with limited English proficiency. Two HHS offices administered six programs: Head Start, CCDF, TANF, SSBG, and two programs that provided grants for residential treatment for substance-abusing women and their infants. The Department of Interior administered one program that provided education and care and served children under age 5-the Indian Child and Family Education program. 
Figure 2: Federal Programs With a Program Purpose of Providing Education and Care That Serve Children Under Age 5, by Federal Department and Office

\section{Department of Education}

$$
\begin{aligned}
& \text { Office of Elementary and Secondary } \\
& \text { Education } \\
& \text { - Title I Grants to Local Educational Agencies } \\
& \text { - Education for Homeless Children and Youth } \\
& \text { - Even Start-State Educational Agencies } \\
& \text { - Reading Excellence } \\
& \text { - Twenty-First Century Community Learning } \\
& \text { Centers } \\
& \text { - Alaska Native Home-Based Education for } \\
& \text { Preschool Children } \\
& \text { - Indian Education-Grants to Local Educational } \\
& \text { - Agencies } \\
& \text { - Even Start-Indian Tribes and Tribal } \\
& \text { Organizations } \\
& \text { - Demonstration Grants for Indian Children } \\
& \text { - Even Start-Migrant Education } \\
& \text { - Native Hawaiian Family-Based Education } \\
& \text { Centers } \\
& \text { - Migrant Education-Basic State Grant Program }
\end{aligned}
$$

Office of Bilingual Education and Minority Languages Affairs

- Bilingual Education

- Program Development and Implementation Grants

- Program Enhancement Grants

- Comprehensive School Grants

- Systemwide Improvement Grants

- Immigrant Education

Office of Special Education and Rehabilitative Services

- Special Education

- Preschool Grants (IDEA)

- Grants for Infants and Families With Disabilities

- Grants to States

Office of Educational Research and Improvement

- Ready-To-Learn Television

Office of Postsecondary Education

- Child Care Access Means Parents in School

\section{Department of Health} and Human Services

\author{
- CCDF \\ - Head Start \\ - TANF \\ - SSBG
}

Administration for Children and Families

Substance Abuse and Mental Health Services Administration

- Grants for Residential Treatment Programs for Pregnant and Postpartum Women

- Demonstration Grants for Residential Treatment for Women and Their Children

\section{Department of Interior}

\author{
Bureau of Indian Affairs \\ - Indian Child and Family Education (FACE)
}


Spending on Education and Care for Children Under Age 5 Varied Widely
About half of the programs that provided data on the proportion of budget authority they spent on education and care for children under age 5 spent a significant amount, more than 40 percent, for this purpose. The other programs that provided data spent 13 percent or less on education and care for children under age 5 . Agencies estimated that their programs spent at least a total of $\$ 9$ billion to provide education and care to children under age 5 in fiscal year 1999 (see table 1). ${ }^{10} \mathrm{HHS}$ administered the three programs that accounted for most of this amount: Head Start ( $\$ 4.4$ billion), CCDF ( $\$ 2.2$ billion), and TANF ( $\$ 1.3$ billion) together spent approximately $\$ 8$ billion of the total $\$ 9$ billion.

Agencies were able to provide the budget authority data we requested for 21 of the 29 programs. About half of the programs that provided data estimated that their programs spent 40 percent or more of their fiscal year 1999 budget authority on education and care for children under age 5 (see table 1). Agency estimates showed, of the 21 programs

- 5 spent at least 90 percent,

- 6 spent between 40 and 70 percent, and

- 10 spent 13 percent or less.

Eight programs could not provide us with the proportion of funding used for children under age 5 , although several of these programs are recognized as important funding sources for education and care for young children. These programs include Title I, Even Start-State E ducational Agencies, and Twenty-F irst Century Community Learning Centers.

Programs spending lesser proportions of their budgets on education and care for children under age 5 devoted resources to other program activities or focused resources on another age group. For example, the SSBG program funded child care and other program activities, such as care for disabled adults. The bilingual education programs estimated spending between 1 and 10 percent of their 1999 budget authority on education and care for children under age 5 . Because these programs funded children in preschool through grade 12 , children under age 5 represented only a small portion of their budgets.

\footnotetext{
${ }^{10}$ E ight programs were unable to provide an estimate for the amount spent on program participants under age 5 .
} 
Agencies were able to report estimates of the number of participants under age 5 who were served by 24 of the 29 programs in fiscal year 1999. The numbers ranged from 102 to over 2 million children. SSBG, Twenty-First Century Community Learning Centers, and CCDF each reported serving over 1 million children in this age group. In contrast, six programs reported serving 500 or fewer children. (See table 2.) How ever, the number of children participating in a program is not the same as the number of children eligible for the program. HHS officials reported that CCDF provided child care subsidies to only 15 percent of eligible families in 1998. HHS officials also reported that Head Start served approximately 38 percent of its eligible children nationwide. ${ }^{11}$

Because program officials used various methods to estimate the number of participants under age 5 in their programs and, as we discuss later, the amount and intensity of services provided vary, tables 1 and 2 cannot be combined to obtain meaningful per-child costs.

Table 1: Federal Spending on Education and Care of Children Under Age 5, Fiscal Year 1999

\begin{tabular}{|c|c|c|c|}
\hline \multirow[b]{2}{*}{ Program } & \multirow[b]{2}{*}{$\begin{array}{r}\text { FY } 1999 \text { budget } \\
\text { authority }\end{array}$} & \multicolumn{2}{|c|}{ Amount for children under age 5} \\
\hline & & Estimated amount & $\begin{array}{r}\text { Percentage of } \\
\text { total budget } \\
\text { authority }\end{array}$ \\
\hline Head Start & $\$ 4,658,151,448$ & $\$ 4,378,662,000$ & 94 \\
\hline CCDF & $3,166,000,000$ & $2,216,200,000$ & 70 \\
\hline TANF & $17,052,515,000$ & $1,278,938,625$ & 7.5 \\
\hline $\begin{array}{l}\text { Special Education-Grants for Infants and Families With } \\
\text { Disabilities }\end{array}$ & $370,000,000$ & $370,000,000$ & 100 \\
\hline Special Education-Grants to States & $4,310,700,000$ & $258,642,000$ & 6 \\
\hline SSBG & $1,900,000,000$ & $209,000,000$ & 11 \\
\hline Special Education-Preschool Grants (IDEA) & $373,985,000$ & $205,692,000$ & 55 \\
\hline Ready-To-Learn Television & $11,000,000$ & $11,000,000$ & 100 \\
\hline Indian Child and Family Education (FACE) & $5,471,000$ & $5,197,450$ & 95 \\
\hline Child Care Access Means Parents in School & $5,000,000$ & $4,750,000$ & 95 \\
\hline Alaska Native Home-Based Education for Preschool Children & $10,000,000$ & $4,343,359$ & 43.4 \\
\hline
\end{tabular}

\footnotetext{
${ }^{11}$ See GAO/HEHS-00-11.
} 


\begin{tabular}{|c|c|c|c|}
\hline \multirow[b]{2}{*}{ Program } & \multirow[b]{2}{*}{$\begin{array}{r}\text { FY } 1999 \text { budget } \\
\text { authority }\end{array}$} & \multicolumn{2}{|c|}{ Amount for children under age 5} \\
\hline & & Estimated amount & $\begin{array}{r}\text { Percentage of } \\
\text { total budget } \\
\text { authority }\end{array}$ \\
\hline Native Hawaiian Family-Based Education Centers & $7,200,000$ & $4,000,000$ & $55-60$ \\
\hline $\begin{array}{l}\text { Demonstration Grants for Residential Treatment for Women and } \\
\text { Their Children }\end{array}$ & $7,880,208$ & $3,152,083$ & 40 \\
\hline $\begin{array}{l}\text { Grants for Residential Treatment Programs for Pregnant and } \\
\text { Postpartum Women }\end{array}$ & $2,810,973$ & $1,124,389$ & 40 \\
\hline $\begin{array}{l}\text { Bilingual Education-Program Development and Implementation } \\
\text { Grants }\end{array}$ & $10,800,000$ & $1,080,000$ & 10 \\
\hline Bilingual Education-Program Enhancement Grants & $10,000,000$ & $1,000,000$ & $\overline{10}$ \\
\hline Bilingual Education-Comprehensive School Grants & $90,900,000$ & 909,000 & $\overline{1}$ \\
\hline Bilingual Education- Systemwide Improvement Grants & $42,100,000$ & 421,000 & $\overline{1}$ \\
\hline Indian Education-Grants to Local Educational Agencies & $62,000,000$ & 248,000 & 0.4 \\
\hline Demonstration Grants for Indian Children & $1,265,000$ & 75,900 & 6 \\
\hline Migrant Education-Basic State Grant Program & 354,689 & 46,110 & 13 \\
\hline Title I Grants to Local Educational Agencies & $7,700,000,000$ & a & $\bar{a}$ \\
\hline Immigrant Education & $150,000,000$ & a & $\bar{a}$ \\
\hline Education for Homeless Children and Youth & $28,800,000$ & a & $\bar{a}$ \\
\hline Even Start-State Educational Agencies & $125,250,000$ & a & $\bar{a}$ \\
\hline Even Start-Migrant Education & $4,050,000$ & a & $\bar{a}$ \\
\hline Twenty-First Century Community Learning Centers & $200,000,000$ & a & $\bar{a}$ \\
\hline Reading Excellence & $241,100,000$ & $\mathrm{~b}$ & $\bar{b}$ \\
\hline Even-Start-Indian Tribes and Tribal Organizations & $2,025,000$ & a & $\bar{a}$ \\
\hline Total & $\$ 40,549,358,318$ & $\$ 8,954,481,916$ & \\
\hline
\end{tabular}

${ }^{a}$ Agency officials were unable to estimate the amount spent on children under age 5 on our data collection instrument.

${ }^{\mathrm{b}}$ This is a new program. Monies were awarded to the states in August 1999 for elementary school children in grades K-3. States are now in the process of awarding the first subgrants to schools.

Table 2: Estimated Number of Participants Under Age 5 in Fiscal Year 1999, by Program

\section{Program}

SSBG

Twenty-First Century Community Learning Centers
Estimated number of participants Agency $\mathrm{HHS}$ nder age $5^{\mathrm{a}}$ $2,320,067^{b}$ Education $1,760,000$

Continued 


\begin{tabular}{|c|c|c|}
\hline Program & Agency & $\begin{array}{r}\text { Estimated number } \\
\text { of participants } \\
\text { under age } 5^{\text {a }}\end{array}$ \\
\hline CCDF & HHS & $1,260,000$ \\
\hline Head Start & HHS & 780,200 \\
\hline Special Education-Grants to States & Education & 574,713 \\
\hline TANF & HHS & $350,000^{\circ}$ \\
\hline Title I Grants to Local Educational Agencies & Education & 300,000 \\
\hline Special Education-Preschool Grants (IDEA) & Education & 316,000 \\
\hline Special Education-Grants for Infants and Families With Disabilities & Education & 186,819 \\
\hline Migrant Education-Basic State Grant Program & Education & 69,251 \\
\hline Even-Start-State Educational Agencies & Education & 25,500 \\
\hline Native Hawaiian Family-Based Education Centers & Education & 2,100 \\
\hline Indian Education-Grants to Local Educational Agencies & Education & 2,000 \\
\hline Indian Child and Family Education (FACE) & Interior & 1,800 \\
\hline Bilingual Education-Program Development and Implementation Grants & Education & 1,000 \\
\hline Bilingual Education-Program Enhancement Grants & Education & 1,000 \\
\hline Bilingual Education- Systemwide Improvement Grants & Education & 1,000 \\
\hline Even Start-Migrant Education & Education & 940 \\
\hline Bilingual Education-Comprehensive School Grants & Education & 500 \\
\hline Even Start-Indian Tribes and Tribal Organizations & Education & 240 \\
\hline Demonstration Grants for Residential Treatment for Women and Their Children & HHS & 235 \\
\hline Demonstration Grants for Indian Children & Education & 150 \\
\hline Alaska Native Home-Based Education for Preschool Children & Education & 120 \\
\hline Grants for Residential Treatment Programs for Pregnant and Postpartum Women & $\mathrm{HHS}$ & 102 \\
\hline Child Care Access Means Parents in School & Education & d \\
\hline Education for Homeless Children and Youth & Education & d \\
\hline Immigrant Education & Education & d \\
\hline Reading Excellence & Education & d \\
\hline Ready-To-Learn Television & Education & \\
\hline
\end{tabular}

Continued from Previous Page

${ }^{a}$ We did not compute a total because children may have participated in more than one of the programs listed. For example, a 3-year-old with a disability may have received services under Education's Special Education-Preschool Grants as well as under its Special Education-Grants to States program.

${ }^{b}$ Agency officials do not collect participation data for children under age 5 . The reported estimate includes all children receiving day care, a high proportion of whom are assumed to be under age 5 .

${ }^{c}$ This number is based on monthly enrollment.

${ }^{\mathrm{d} A g e n c y}$ officials were not able to provide an estimate of the number of children under age 5 who participated in the program in fiscal year 1999 .

${ }^{\mathrm{e}}$ The agency reported that $4,827,540$ children ages 3 to 8 participated in the program in fiscal year 1999 , but was not able to provide an estimate for the number of children under age 5 who participated in the program. 
Programs Target Particular Groups and Provide Some of the Same Types of Services
The 29 programs that provided education and care to children under age 5 targeted three major groups of children. Most programs were allowed to provide a broad range of services such as health, mental health, and nutritional services. Four programs provided most of these services to a large proportion of the participants under age 5.

\section{Programs Targeted Three Groups}

The 29 federal programs that provided education and care to children under age 5 generally targeted children who

- were economically disadvantaged,

- had special needs, or

- were members of certain native populations. ${ }^{12}$

During fiscal year 1999, 10 programs (including Head Start, CCDF, and TANF - the three largest programs in terms of spending for children under age 5) targeted economically disadvantaged children. Thirteen programs targeted children with various special needs, such as disabilities or limited English proficiency, as well as migrant or immigrant children. Six programs targeted native populations, including Native American Indians, Alaskans, and Hawaiians (see table 3).

The specific eligibility criteria for the 29 programs included a child's age, family income, and other factors. Age criteria varied and often overlapped among programs serving similar target groups. For example, eligibility for three Native American programs included children age 0 to 7, 0 to 8, and 4 through 18. Among programs serving disabled children, one targeted applicants age 0 to 21 while another covered preschoolers age 3 to 5 . A third program provided early intervention services to disabled infants and toddlers under age 3 and their families or, at state option, infants and toddlers at risk of needing special education and related services. Likewise, family income eligibility criteria varied, with the federal government, states, and school districts defining "low income" differently for different programs, resulting in overlap of income criteria. For example, income eligibility criteria for TANF are set by each state, within certain federal guidelines. How ever, Title I funds are allocated among states and schools

${ }^{12}$ Target groups are not necessarily mutually exclusive. 
based on formulas that take into account the number of children whose family income is below the federal poverty line.

While programs may serve the same target group, specific eligibility requirements limit the number of children eligible to receive services. For example, an economically disadvantaged child may not be eligible for both CCDF and Head Start- two programs that target this type of childbecause of differences in income eligibility requirements. CCDF provides child care subsidies for families with children under age 13 whose family income does not exceed 85 percent of the state median income. ${ }^{13} \mathrm{Head}$ Start primarily targets preschool children from families whose income is under the federal poverty line. ${ }^{14} \mathrm{~A}$ child could only be eligible for both programs if that child was of kindergarten age or younger, as required by Head Start, and if family income was at or below the lower of federal poverty line or the CCDF income level set by the state.

In some cases, participation in more than one program may be beneficial. For example, because Head Start is usually a part-day program, working parents might need both the preschool education of Head Start and the child care of CCDF to ensure that their children are taken care of for a full day while the parents are at work.

Table 3: Federal Programs That Provide Education and Care to Children Under Age 5, by Target Group

\begin{tabular}{|c|c|c|}
\hline Program & Program description & Beneficiary eligibility criteria \\
\hline \multicolumn{3}{|c|}{ Economically disadvantaged } \\
\hline CCDF & $\begin{array}{l}\text { Grants to states for subsidizing the child care } \\
\text { costs of eligible families and to improve the } \\
\text { overall quality and availability of child care } \\
\text { services. Some CCDF funds are subject to } \\
\text { matching requirements. }\end{array}$ & $\begin{array}{l}\text { Children up to age } 13 \text { who reside with a family } \\
\text { whose income does not exceed } 85 \% \text { of the state } \\
\text { median income. Parent(s) must be working or in } \\
\text { education or training, or the child must be in need of } \\
\text { protective services. States set eligibility within } \\
\text { federal rules. }\end{array}$ \\
\hline
\end{tabular}

${ }^{13}$ States set eligibility rules within this federal guideline. In practice, many states set eligibility at lower levels.

${ }^{14}$ Ninety percent of Head Start participants must have family income below the federal poverty line. 


\begin{tabular}{|c|c|c|}
\hline Program & Program description & Beneficiary eligibility criteria \\
\hline $\begin{array}{l}\text { Title I Grants to Local } \\
\text { Educational Agencies }\end{array}$ & $\begin{array}{l}\text { Formula grants through states to local } \\
\text { educational agencies for supplementary } \\
\text { educational and related services to educationally } \\
\text { disadvantaged children living in relatively low- } \\
\text { income areas }\end{array}$ & $\begin{array}{l}\text { Children aged pre-kindergarten to } 21 \text { who are failing } \\
\text { or at risk of failing state academic standards who } \\
\text { live in low-income areas }\end{array}$ \\
\hline $\begin{array}{l}\text { Education for Homeless } \\
\text { Children and Youth }\end{array}$ & $\begin{array}{l}\text { Formula grants to the states to ensure that } \\
\text { homeless children have equal access to the } \\
\text { education programs available to other children, } \\
\text { including preschool-aged children }\end{array}$ & $\begin{array}{l}\text { Homeless children and youth in preschool, } \\
\text { elementary, and secondary schools or who should } \\
\text { be enrolled in school but are not }\end{array}$ \\
\hline $\begin{array}{l}\text { Even Start-State Educational } \\
\text { Agencies }\end{array}$ & $\begin{array}{l}\text { Formula grants to states for discretionary } \\
\text { subgrants to partnerships between local } \\
\text { educational agencies and nonprofit entities to } \\
\text { improve the educational opportunities of low- } \\
\text { income families through family literacy programs } \\
\text { that integrate early childhood education, adult } \\
\text { basic education, and parenting education }\end{array}$ & $\begin{array}{l}\text { Children aged birth to } 8 \text { years, who come from low- } \\
\text { income families, and whose parents have basic } \\
\text { literacy needs }\end{array}$ \\
\hline $\begin{array}{l}\text { Child Care Access Means } \\
\text { Parents in Schools }\end{array}$ & $\begin{array}{l}\text { Grants to institutions of higher learning to support } \\
\text { the participation of low-income parents in } \\
\text { postsecondary education through the provision of } \\
\text { campus-based child care services }\end{array}$ & $\begin{array}{l}\text { Low-income students in postsecondary programs } \\
\text { who themselves have children and require child care } \\
\text { services }\end{array}$ \\
\hline Reading Excellence & $\begin{array}{l}\text { Grants to states to provide children with the } \\
\text { readiness skills and support they need to learn to } \\
\text { read once they enter school or by the end of third } \\
\text { grade }\end{array}$ & $\begin{array}{l}\text { Children in grades pre-kindergarten through third } \\
\text { grade, who are enrolled in schools with a high } \\
\text { concentration of poverty }\end{array}$ \\
\hline TANF & $\begin{array}{l}\text { Block grants to states for temporary income } \\
\text { assistance to needy families with children. States } \\
\text { may spend block grants for child care and other } \\
\text { purposes consistent with the law }\end{array}$ & $\begin{array}{l}\text { Families who have a child living with a parent or } \\
\text { other adult relative and are needy, or who meet } \\
\text { CCDF eligibility standards for states that transfer } \\
\text { TANF funds to CCDF }\end{array}$ \\
\hline Head Start & $\begin{array}{l}\text { Grants to agencies to provide comprehensive } \\
\text { early childhood developmental, educational, } \\
\text { health, nutritional, social, and other services to } \\
\text { primarily low-income children and their families }\end{array}$ & $\begin{array}{l}\text { Children from birth through kindergarten age; } 90 \% \\
\text { must be from families whose income is below the } \\
\text { poverty line or families who are eligible for public } \\
\text { assistance }\end{array}$ \\
\hline SSBG & $\begin{array}{l}\text { Block grants to states to provide social services, } \\
\text { including child day care, at the states' discretion }\end{array}$ & $\begin{array}{l}\text { States decide which services benefit children and } \\
\text { the criteria for eligibility }\end{array}$ \\
\hline $\begin{array}{l}\text { Twenty-First Century } \\
\text { Community Learning Centers }\end{array}$ & $\begin{array}{l}\text { Discretionary/competitive grants to individual } \\
\text { rural or inner-city schools, or consortia of such } \\
\text { schools, for activities that benefit the educational, } \\
\text { health, social services, cultural, and recreational } \\
\text { needs of their community }\end{array}$ & $\begin{array}{l}\text { Residents of all ages in selected rural and inner city } \\
\text { communities, in particular, young children }\end{array}$ \\
\hline \multicolumn{3}{|l|}{ Special needs } \\
\hline \multicolumn{3}{|l|}{ Disabled children } \\
\hline $\begin{array}{l}\text { Special Education-Grants to } \\
\text { States }\end{array}$ & $\begin{array}{l}\text { Grants to states to assist them in providing a free } \\
\text { appropriate public education to all children with } \\
\text { disabilities }\end{array}$ & $\begin{array}{l}\text { Children, aged } 0 \text { through } 21 \text {, with a disability who } \\
\text { need special education and related services in } \\
\text { public schools }\end{array}$ \\
\hline
\end{tabular}




\begin{tabular}{ll}
\hline Program & Program description \\
\hline Special Education-Preschool & $\begin{array}{l}\text { Grants to assist states in providing special } \\
\text { education and related services to preschool-aged } \\
\text { children with disabilities who are in need of } \\
\text { special education. At state option, children } \\
\text { experiencing developmental delays may also be } \\
\text { considered disabled. }\end{array}$ \\
\hline Special Education-Grants for & $\begin{array}{l}\text { Formula grants to help states develop and } \\
\text { Infants and Families with }\end{array}$ \\
Disabilities & $\begin{array}{l}\text { coordinated, multidisciplinary, interagency system } \\
\text { to provide early intervention services for infants } \\
\text { and toddlers with disabilities and their families }\end{array}$
\end{tabular}

\section{Beneficiary eligibility criteria}

Children aged 3 to 5 who have a disability, and at a state's discretion, 2-year-old children with disabilities who will turn 3 years old during the school year and need special education and related services

\section{Infants or toddlers under 3 years of age with a} disability who need early intervention services because of developmental delays or at states' option, at-risk infants and toddlers

\section{Children with limited English \\ proficiency}

Bilingual Education-Program

Development and

Implementation Grants

Bilingual Education-Program

Enhancement Grants

Bilingual Education-

Comprehensive School Grants

Bilingual Education-

Systemwide Improvement Grants

Ready-To-Learn Television
Grants to local education agencies to implement new comprehensive bilingual programs

Grants to local education agencies to expand or enhance existing bilingual programs

Grants to local education agencies (in which schools have at least 25\% limited English proficiency enrollment) for reforming all relevant bilingual programs

Grants to local education agencies or local education agencies' consortia (with more than 1,000 or $25 \%$ limited English proficiency enrollment) for reforming districtwide bilingual programs

Grants to develop educational programming for preschool and early elementary school children and their families to increase school readiness, with an emphasis on the needs of children in limited English proficient households and to increase family literacy

\section{Migrants}

Migrant Education-Basic State Grants to the states for providing supplemental Grant Program education and related services for migratory children of migrant agricultural workers and migrant fishers

Even Start-Migrant Education Discretionary grants to state educational agencies, local education agencies, and nonprofit organizations to improve the educational opportunities of migrant families through family literacy programs that integrate early childhood education, adult literacy or adult basic education, and parenting education
Limited English proficient children who are enrolled in preschool through grade 12

Limited English proficient children who are enrolled in preschool through grade 12

Limited English proficient children who are enrolled in preschool through grade 12

Limited English proficient children who are enrolled in preschool through grade 12

All children generally and children in limited English proficient households, their parents, child care providers, and Head Start programs
Children and youth aged 0 to 21 who are, or whose parent, spouse, or guardians are, migratory workers or migratory fishers

Children of migratory agriculture workers or migratory fishers and their parents. Children must be 0 to 8 years old and come from low-income families; parents must have basic literacy needs 


\begin{tabular}{lll}
\hline Program & Program description & Beneficiary eligibility criteria \\
\hline Immigrants & & \\
\hline Immigrant Education & Formula grants to states for educational services & Immigrant children in grades pre-kindergarten \\
& $\begin{array}{l}\text { and costs for immigrant children enrolled in } \\
\text { elementary and secondary public and nonpublic }\end{array}$ & through 12 who have been enrolled in U.S. schools \\
& schools. States provide funding to local education 3 years & \\
& agencies with at least 500 or 3 percent immigrant & \\
& enrollment & \\
\hline
\end{tabular}

Substance-abusing women with children

Demonstration Grants for Grants to states for alcohol and other drug abuse Children aged 1 to 10 whose mothers have

Residential Treatment for

Women and Their Children ${ }^{\mathrm{c}}$ setting coupled with primary health, mental treatment services delivered in a residential health, and social services (including child care and educational development services for children with exposure to alcohol and other drugs) for parenting women and their children

Grants for Residential Treatment Programs for Pregnant and Postpartum Women $^{\mathrm{c}}$
Grants to states for alcohol and other drug abuse treatment services delivered in a residential setting coupled with primary health, mental health, and social services (including child care and developmental services for infants and other children with intrauterine and environmental exposure to alcohol and other drugs) for women, their infants, and other children

\section{Native populations}

Native American Indian

Indian Child and Family Education (FACE)

\section{Indian Education-Grants to} Local Educational Agencies
Grants to Indian tribal governments and tribal organizations to begin educating Native American children at an early age through parental involvement, increase high school graduation rates among Indian parents, and encourage lifelong learning

Grants to local education agencies that enroll at least 10 Indian children or in which Indians constitute at least $25 \%$ of the total enrollment to reform elementary and secondary school programs that serve Indian students in order to ensure that programs are based on standards that are used for all students

Demonstration Grants for Indian Children
Grants to provide financial assistance to projects to develop, test, and demonstrate the effectiveness of services and programs to improve the educational opportunities and achievement of preschool, elementary, and secondary school Indian children
Native American parents and their children, aged 0 to 8 years, who live on a reservation within boundaries of a Bureau of Indian Affairs (BIA)funded school

Native American Indian children enrolled in BIAfunded or -operated local educational agencies

Native American Indian preschool, elementary, and secondary children 


\begin{tabular}{|c|c|c|}
\hline Program & Program description & Beneficiary eligibility criteria \\
\hline $\begin{array}{l}\text { Even Start-Indian Tribes and } \\
\text { Tribal Organizations }\end{array}$ & $\begin{array}{l}\text { Discretionary grants to federally recognized } \\
\text { Indian tribes and tribal organizations for family } \\
\text { literacy programs that integrate early childhood } \\
\text { education, adult basic education, and parenting } \\
\text { education }\end{array}$ & $\begin{array}{l}\text { Native American Indian children aged } 0 \text { to } 8 \text { years } \\
\text { who come from low-income families, and whose } \\
\text { parents have basic literacy needs }\end{array}$ \\
\hline \multicolumn{3}{|l|}{ Native Hawaiian } \\
\hline $\begin{array}{l}\text { Native Hawaiian Family-Based } \\
\text { Education Centers }\end{array}$ & $\begin{array}{l}\text { Grants to Native Hawaiian organizations in Hawaii } \\
\text { for the operation of centers whose activities } \\
\text { include parent-infant programs for the prenatal } \\
\text { period through age 3, preschool programs to } \\
\text { serve 4- to 5-year-olds, research and } \\
\text { development, and project assessments }\end{array}$ & $\begin{array}{l}\text { Hawaiian infants up to age } 3 \text { and Hawaiian } \\
\text { preschoolers aged } 4 \text { to } 5\end{array}$ \\
\hline \multicolumn{3}{|l|}{ Alaskan Natives } \\
\hline $\begin{array}{l}\text { Alaska Native Home-Based } \\
\text { Education for Preschool } \\
\text { Children }\end{array}$ & $\begin{array}{l}\text { Grants to Alaskan Native organizations or } \\
\text { educational entities to implement home } \\
\text { instruction programs for Alaskan Native preschool } \\
\text { youngsters }\end{array}$ & Alaskan Native children aged 0 through 5 \\
\hline
\end{tabular}

Continued from Previous Page

${ }^{a}$ Although CCDF primarily serves low-income families, states may serve families who earn up to 85 percent of the state median income.

${ }^{b}$ According to agency officials, while this program can provide services to pre-kindergartners, the priority for fiscal year 2000 is kindergarten through grade 3 .

${ }^{c}$ According to agency officials, no new grants were to be awarded in fiscal year 2000.

\section{Some Programs Provided Some of the Same Types of Services}

In addition to providing early childhood education and care, most of the 29 programs were allowed to provide a broad range of supplemental services, including health, dental, mental health, social, parental, and nutritional services; speech and hearing assessments; and disability screening. Four programs-Head Start, Even Start-Migrant E ducation, and the two residential treatment programs for substance-abusing mothers and their children-provided the widest range of services, with each providing 9 of the 10 services we asked about to all or most children participating in the program. All four reported providing the same seven services to all or most children under age 5 participating in the program: early childhood education, health services, speech and hearing assessments, disability screening, social services, parental services, and nutritional services.

Most programs reported providing supplemental services to a small proportion of program participants under age 5 or were unable to provide estimates. For example, the Migrant E ducation-B asic State Grant Program estimated that it provided early childhood education, health services, and services to parents to "some" children; dental and nutritional services to a 
"few" children; and social services to "about half" of the program participants under age 5. The Twenty-F irst Century Community Learning Centers program estimated that it provided early childhood education to some children and child care, health, dental, social, and mental health services; speech or hearing assessments; and disability screening to a few of the program participants under age 5. Two of the four programs targeting Native American children-Indian Child and Family E ducation, administered by Interior, and E ven Start-Indian Tribes and Tribal Organizations, administered by Education-reported providing early childhood education, parental, and nutritional services to all or most of the Native American children and their parents participating in their programs (see table 4). Several programs, including the Special E ducation-Preschool Grants, Child Care Access Means Parents in School, and SSBG programs, were not able to report the number of children under age 5 served for many of the services about which we asked. (See app. II for the proportion of each programs' participants who received each service.)

Table 4: Programs Targeting Native American Children-Proportion of Participating Children Under Age 5 Receiving Services

\begin{tabular}{|c|c|c|c|c|c|c|c|c|c|c|}
\hline \multirow[b]{2}{*}{ Program } & \multicolumn{10}{|c|}{ Service } \\
\hline & $\begin{array}{l}\text { Early } \\
\text { childhood } \\
\text { education }\end{array}$ & $\begin{array}{l}\text { Child } \\
\text { care }\end{array}$ & $\begin{array}{l}\text { Health } \\
\text { services }\end{array}$ & $\begin{array}{l}\text { Dental } \\
\text { services }\end{array}$ & $\begin{array}{l}\text { Mental } \\
\text { health } \\
\text { services }\end{array}$ & $\begin{array}{l}\text { Speech and } \\
\text { hearing } \\
\text { assessments }\end{array}$ & $\begin{array}{l}\text { Disability } \\
\text { screening }\end{array}$ & $\begin{array}{l}\text { Social } \\
\text { services }\end{array}$ & $\begin{array}{l}\text { Parental } \\
\text { services }\end{array}$ & $\begin{array}{l}\text { Nutritional } \\
\text { services }\end{array}$ \\
\hline $\begin{array}{l}\text { Indian Child and } \\
\text { Family Education } \\
\text { (FACE) }\end{array}$ & $\begin{array}{l}\text { All or } \\
\text { nearly all }\end{array}$ & $\mathrm{a}$ & $\mathrm{a}$ & $\mathrm{a}$ & $\mathrm{a}$ & All or nearly all & $\begin{array}{l}\text { All or } \\
\text { nearly all }\end{array}$ & $\mathrm{a}$ & $\begin{array}{l}\text { All or } \\
\text { nearly all }\end{array}$ & $\begin{array}{l}\text { All or } \\
\text { nearly all }\end{array}$ \\
\hline $\begin{array}{l}\text { Even-Start- } \\
\text { Indian Tribes and } \\
\text { Tribal } \\
\text { Organizations }\end{array}$ & $\begin{array}{l}\text { All or } \\
\text { nearly all }\end{array}$ & Most & Most & Some & Some & Some & Some & $\begin{array}{l}\text { All or } \\
\text { nearly all }\end{array}$ & $\begin{array}{l}\text { All or } \\
\text { nearly all }\end{array}$ & $\begin{array}{l}\text { All or } \\
\text { nearly all }\end{array}$ \\
\hline $\begin{array}{l}\text { Indian } \\
\text { Education- } \\
\text { Grants to Local } \\
\text { Educational } \\
\text { Agencies }\end{array}$ & Few & None & Few & Few & Few & Few & Few & Few & Few & Few \\
\hline $\begin{array}{l}\text { Demonstration } \\
\text { Grants for Indian } \\
\text { Children }\end{array}$ & Some & Some & Some & Some & Few & Few & Few & Few & Some & Some \\
\hline
\end{tabular}


Similarly, programs targeting children with limited English proficiency delivered some of the same types of services to children under age 5 participating in these programs. Four bilingual education programsProgram Development and Implementation Grants, Program E nhancement Grants, Comprehensive School Grants, and Systemwide Improvement Grants- reported providing early childhood education and parental services to all or most of their participants under age 5. In addition, all four programs reported providing social services to some participants under age 5. Two of the programs also reported providing child care to some of the participants in this age group.

Ten programs that targeted economically disadvantaged children provided some of the same types of services. For example, 7 of the 10 programs provided parental services and 5 programs provided nutritional services to all or most children participating in their programs (see app. II). Five of the 10 programs reported providing early childhood education to a high proportion of participants under age 5 . The remaining programs provided early childhood education and care to a small proportion of participants in this age group or could not provide an estimate.

Additional Data Needed to Determine If Inefficiencies Result From Overlap
When multiple agencies manage multiple early childhood education and care programs, mission fragmentation and program overlap occur. Though sometimes necessary to meet federal priorities, mission fragmentation and overlapping programs can create an environment in which participants are not served as efficiently and effectively as possible. ${ }^{15}$ Policymakers could choose to coordinate, integrate, or consolidate programs to address inefficiencies that may arise; how ever, information beyond the scope of this report would be needed to identify the degree of program inefficiencies and the best method for addressing any inefficiencies. Policymakers need to ask, among other things, whether programs are fulfilling a unique role or effectively meeting program as well as federal strategic goals. Information required by GPRA should provide answers to some of these questions and ultimately help to guide this effort.

Mission fragmentation was evident among the 29 early childhood education and care programs we examined. These programs were administered by eight offices in three federal departments. In addition, many of the 29 2000) and GAO/T-HEHS-99-93. 
programs provided similar services to the same target groups. Overlap was evident among programs serving young Native American and limited English proficient children. For example, all four programs serving Native American children, administered by Education and Interior, provided educational, parental, and nutritional services; speech and hearing assessments; and disability screening to participants, and although each could serve children of various ages, some participants were under age 5 . Education's four bilingual education programs all provided early childhood education, parental services, and social services to young children with limited English proficiency.

Past GAO work has shown that program overlap increases the likelihood that inefficiencies such as duplicative programs-those providing identical services to identical target groups-will result. Duplicative programs can waste administrative resources and confuse those seeking services. Program overlap can also increase the chance of gaps in services. One way service gaps can occur is when all members of a target population are not being served by existing programs because differing program eligibility requirements unintentionally exclude them. Gaps in services may also result when programs do not provide adequate coverage to fully meet participant needs. For example, children in low-income families may not be eligible for both Head Start and CCDF, which could make it difficult for parents to work or attend school full-time. Collaborative arrangements between Head Start, generally a part-day program, and programs such as CCDF may be needed to provide full day care in order to prevent service gaps so parents can work full-time.

To address inefficiencies such as program duplication and service gaps that can arise from mission fragmentation and program overlap, one of several approaches could be taken: coordination, integration, or consolidation. Policymakers could direct responsible agencies to better coordinate programs with other agencies that share the same program mission. Responsible agencies could also integrate program services from one program into others to more effectively serve certain target groups. Service integration activities range from providing services from several agencies at one location to creating state and local interagency service planning and budgeting functions. Policymakers and responsible agencies could also decide that the only way to eliminate duplicative programs is to consolidate several into one. However, to determine the most appropriate method of addressing problems created by mission fragmentation and program overlap, policymakers would need to consider, among other things, whether 
- overlapping programs fulfill unique roles or are unnecessarily duplicative,

- some programs are more effective at meeting program and federal strategic goals than others, and

- whether some other configuration of programs might better serve participants.

To learn whether specific programs play unique roles or are unnecessarily duplicative, policymakers would need to know the means used to accomplish program goals and the specific services the programs provide. Further study of these program features may highlight important differences among programs that appear to be duplicative. Data on the type and quality of services delivered and the number of children receiving similar services from more than one program would also help to identify programs that meet unique needs and serve unique populations and would be useful in determining the extent of duplication among programs. For example, four programs reported providing dental services to economically disadvantaged young children in fiscal year 1999; however, one may have provided screenings whereas another may have provided more comprehensive dental services including preventive care and treatment.

Assessing whether programs are effective at achieving their program goals requires information on program performance and program evaluations. GPRA requires agencies to collect this type of information and report on it in annual performance plans. Program performance data can be used to assess progress toward established goals. Evaluation results, where available, can provide information about how effective programs are at achieving desired outcomes. With this information, the Congress and the administration may be able to identify some programs that are more effective than others at achieving overall federal goals in the early childhood education and care area. Finally, decisions made about coordinating, integrating, or consolidating programs could affect participants differently and have administrative and budgetary effects on state and local governments, especially if service delivery mechanisms change. 
The Congress and agencies have begun to address problems that result from overlapping early childhood education and care programs through improved coordination and integration and program consolidation. ${ }^{16}$ For example, in 1996, Congress consolidated funding for four child care programs into one-CCDF. The Congress also created the Federal Interagency Coordinating Council to focus on issues related to young children (birth through age 5) who have or are at risk of disabilities. Agencies have also begun to address problems that result from overlapping programs. For example, as we reported in March 1999, HHS and Education are coordinating Head Start and E ven Start programs with one another to improve the quality of family literacy for disadvantaged families with young children through joint training activities. Moreover, Even Start programs are required to build on existing services to minimize potential duplication and sometimes rely on the Head Start program to provide the early childhood education component for Even Start participants ages 3 and 4. In addition, HHS' Head Start Bureau has instituted a number of initiatives among relevant agencies to facilitate collaboration and thus avoid inefficiencies that can be caused by mission fragmentation and program overlap of early childhood education and care programs. For example, HHS has begun to promote collaboration by requiring some Head Start grantees to use collaborative planning processes in order to compete for funds. To compete for Head Start Collaboration Grants, these grantees must provide full-day, full-year services for Head Start, ensure a collaborative planning process with community programs and providers, and combine Head Start funds with available state, local, and private sector funding for child care, pre-kindergarten, and special education services. report; responses from Education and HHS are reprinted in app. III and IV. Interior officials stated that they had no comments.

In its comments, Education said that the report provides a comprehensive overview of federal programs providing education and care for children under age 5 and that some programs have overlapping purposes and target populations. HHS said that the report provides a useful conceptual framework for thinking about the services that are available to young children and their families. However, while E ducation agreed that some of

${ }^{16}$ See GAO/T-HE HS-99-93 and GAO/HE HS-99-136R. 
the programs we report on have overlapping purposes, it was concerned that we be explicit that overlap does not necessarily result in redundancy. HHS also expressed concerns that the report draws unsupported conclusions about mission fragmentation and program overlap.

From their comments, it appears that E ducation and HHS attribute different meanings to the terms "overlap," "fragmentation," and "duplication." We defined mission fragmentation as the involvement of multiple agencies in the same programmatic area; early education and care programs clearly fall under this definition. We pointed out that fragmentation can lead to overlapping programs and can create the potential for inefficiencies such as duplication. We also pointed out that various programs overlapped because they served the same populations and offered similar services. However, we did not conclude that overlap had resulted in duplication and inefficiency, but only that the potential for duplication and inefficiency exists. We also concluded that the agencies' GPRA reports might be useful for evaluating the effectiveness of programs in meeting their goals.

Education and HHS expressed concern that we had not adequately discussed their coordination efforts, so we added some information about ongoing agency efforts to address issues raised by overlapping programs through improved coordination and service integration. Education and HHS also provided technical comments, which we incorporated where appropriate.

We are sending copies of this report to the Honorable Donna E. Shalala, Secretary of the Department of Health and Human Services; the Honorable Richard W. Riley, Secretary of the Department of Education; the Honorable Bruce Babbitt, Secretary of the Interior; and appropriate congressional committees. We will also make copies available to others upon request. 
If you or your staff have any questions about this report, please contact me or Karen Whiten on (202) 512-7215. Martha E Ibaum and Karen Brown made key contributions to this report.

Sincerely yours,

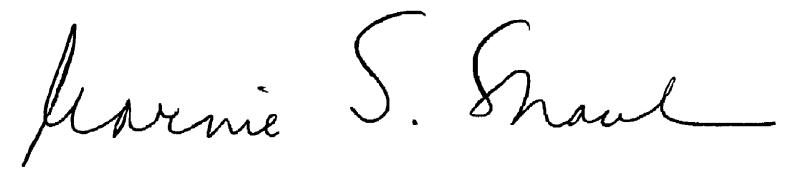

Marnie S. Shaul

Associate Director, Education, Workforce, and Income Security Issues 


\section{Federal Programs That Provided or Supported Education and Care for Children Under 5 Years of Age, Fiscal Year 1999}

\begin{tabular}{ll} 
CFDA number $^{\mathrm{a}}$ & Program name $^{\text {Agriculture }}$ \\
\hline 10.550 & Food Distribution Program \\
\hline 10.553 & School Breakfast Program \\
\hline 10.555 & National School Lunch Program \\
\hline 10.556 & Special Milk Program for Children \\
\hline 10.558 & Child and Adult Care Food Program \\
\hline 10.559 & Summer Food Service Program for Children \\
\hline 10.564 & Nutrition, Education and Training Program \\
\hline
\end{tabular}

\section{Housing and Urban Development}

$14.218 \quad$ Community Development Block Grants/Entitlement Grants

$14.219 \quad$ Community Development Block Grants/Small Cities Program

$14.231 \quad$ Emergency Shelter Grants Program

$14.235 \quad$ Supportive Housing Program (transitional housing)

$14.870 \quad$ Resident Opportunity and Supportive Services

Interior

$15.043 \quad$ Indian Child and Family Education (FACE)

Justice

$16.201 \quad$ Cuban and Haitian Entrant Resettlement Program

$16.730 \quad$ Reduction and Prevention of Children's Exposure to Violence (Safe Start)

Labor

17.211 Job Corps

$17.247 \quad$ Migrant and Seasonal Farmworkers

$17.251 \quad$ Native American Employment and Training Program

$17.255 \quad$ Workforce Investment Act

Appalachian Regional Commission

$23.002 \quad$ Appalachia-Supplements to Federal Grant-in-Aid (area development)

\section{General Services Administration}

$39.003 \quad$ Donation of Federal Surplus Personal Property

Education

84.010 Title I Grants to Local Educational Agencies (basic, concentration, and targeted grants)

84.011 Migrant Education-Basic State Grant Program

$84.027 \quad$ Special Education-Grants to States

$84.041 \quad$ Impact Aid

$84.060 \quad$ Indian Education-Grants to Local Educational Agencies 


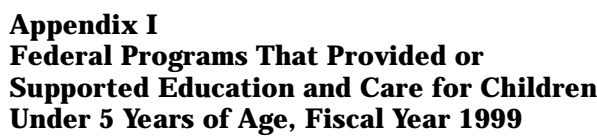

\begin{tabular}{|c|c|}
\hline CFDA number ${ }^{a}$ & Program name \\
\hline 84.162 & Immigrant Education \\
\hline 84.173 & Special Education-Preschool Grants (IDEA) \\
\hline 84.181 & Special Education-Grants for Infants and Families with Disabilities \\
\hline 84.186 & Safe and Drug-Free Schools and Communities-State Grants \\
\hline 84.196 & Education for Homeless Children and Youth \\
\hline 84.209 & Native Hawaiian Family Based Education Centers \\
\hline 84.213 & Even Start-State Educational Agencies \\
\hline 84.214 & Even Start-Migrant Education \\
\hline 84.258 & Even Start-Indian Tribes and Tribal Organizations \\
\hline 84.276 & Goals 2000-State and Local Education Systemic Improvement \\
\hline 84.282 & Charter Schools \\
\hline 84.287 & Twenty-First Century Community Learning Centers \\
\hline 84.288 & Bilingual Education-Program Development and Implementation Grants \\
\hline 84.289 & Bilingual Education-Program Enhancement Grants \\
\hline 84.290 & Bilingual Education-Comprehensive School Grants \\
\hline 84.291 & Bilingual Education-Systemwide Improvement Grants \\
\hline 84.295 & Ready-To-Learn Television \\
\hline 84.296 & Native Hawaiian Community-Based Education Learning Centers \\
\hline 84.298 & Innovative Education Program Strategies \\
\hline 84.299 & Demonstration Grants for Indian Children \\
\hline 84.303 & Technology Innovation Challenge Grants \\
\hline 84.310 & Goals 2000: Parental Assistance Program \\
\hline 84.318 & Technology Literacy Challenge Fund Grants \\
\hline 84.321 & Alaska Native Home-Based Education for Preschool Children \\
\hline 84.323 & Special Education-State Program Improvement Grants for Children With Disabilities \\
\hline 84.327 & Special Education-Technology and Media Services for Individuals With Disabilities \\
\hline 84.332 & Comprehensive School Reform Demonstration \\
\hline 84.335 & Child Care Access Means Parents in School \\
\hline 84.338 & Reading Excellence \\
\hline \multicolumn{2}{|l|}{ HHS } \\
\hline 93.101 & Grants for Residential Treatment Programs for Pregnant and Postpartum Women \\
\hline 93.102 & Demonstration Grants for Residential Treatment for Women and Their Children \\
\hline 93.125 & Mental Health Planning and Demonstration Projects \\
\hline 93.558 & Temporary Assistance for Needy Families (TANF) \\
\hline 93.566 & Refugee and Entrant Assistance-State-Administered Programs \\
\hline 93.571 & Community Services Block Grant Discretionary Awards-Community Food and Nutrition \\
\hline
\end{tabular}


Appendix I

Federal Programs That Provided or

Supported E ducation and Care for Children

Under 5 Years of Age, Fiscal Year 1999

\begin{tabular}{ll}
\begin{tabular}{ll} 
CFDA number \\
\hline 93.575
\end{tabular} & $\begin{array}{l}\text { Program name } \\
\text { funds) }\end{array}$ \\
\hline 93.576 & Refugee and Entrant Assistance-Discretionary Grants \\
\hline 93.583 & Refugee and Entrant Assistance-Wilson/Fish Programs \\
\hline 93.584 & Refugee and Entrant Assistance-Targeted Assistance \\
\hline 93.600 & Head Start \\
\hline 93.645 & Child Welfare Services-State Grants \\
\hline 93.667 & Social Services Block Grant \\
\hline
\end{tabular}

Continued from Previous Page

${ }^{\mathrm{a} C}$ Catalog of Federal Domestic Assistance. 


\section{Proportion of Children Receiving Services From E ducation and Care Programs, by Target Group}

\begin{tabular}{|c|c|c|c|c|c|}
\hline \multirow[b]{2}{*}{ Agency } & \multirow[b]{2}{*}{ Program name } & \multirow[b]{2}{*}{$\begin{array}{l}\text { Estimated number of } \\
\text { children under age } 5 \\
\text { participating }^{\mathrm{a}}\end{array}$} & \multicolumn{3}{|c|}{ Proportion of children under age 5 receiving } \\
\hline & & & $\begin{array}{l}\text { Early childhood } \\
\text { education }\end{array}$ & Child care & $\begin{array}{l}\text { Health } \\
\text { services }\end{array}$ \\
\hline \multicolumn{6}{|c|}{ Economically disadvantaged } \\
\hline HHS & CCDF & $1,260,000$ & Some & All or nearly all & Some \\
\hline Education & $\begin{array}{l}\text { Title I Grants to Local Educational } \\
\text { Agencies }\end{array}$ & 300,000 & All or nearly all & Few & Some \\
\hline Education & $\begin{array}{l}\text { Education for Homeless Children and } \\
\text { Youth }\end{array}$ & Don't know & All or nearly all & Don't know & Some \\
\hline Education & Even-Start-State Educational Agencies & 25,500 & All or nearly all & Some & Some \\
\hline Education & $\begin{array}{l}\text { Child Care Access Means Parents in } \\
\text { School }\end{array}$ & Don't know & All or nearly all & All or nearly all & Don't know \\
\hline Education & Reading Excellence & Don't know & Don't know & Don't know & Don't know \\
\hline HHS & TANF & $350,000^{\circ}$ & Don't know & Most & b \\
\hline $\mathrm{HHS}$ & Head Start & 780,200 & All or nearly all & Some & All or nearly all \\
\hline $\mathrm{HHS}$ & SSBG & $2,320,067^{d}$ & Don't know & Don't know & Don't know \\
\hline Education & $\begin{array}{l}\text { Twenty-First Century Community } \\
\text { Learning Centers }\end{array}$ & $1,760,000$ & Some & Few & Few \\
\hline \multicolumn{6}{|c|}{ Special needs } \\
\hline \multicolumn{6}{|l|}{$\begin{array}{l}\text { Disabled } \\
\text { Children }\end{array}$} \\
\hline Education & Special Education-Grants to States & 574,713 & All or nearly all & $\mathrm{b}$ & Don't know \\
\hline Education & $\begin{array}{l}\text { Special Education-Preschool Grants } \\
\text { (IDEA) }\end{array}$ & 316,000 & All or nearly all & $\mathrm{b}$ & Don't know \\
\hline Education & $\begin{array}{l}\text { Special Education-Grants for Infants and } \\
\text { Families With Disabilities }\end{array}$ & 186,819 & Most & None & Some \\
\hline \multicolumn{6}{|c|}{ Children with limited English proficiency } \\
\hline Education & $\begin{array}{l}\text { Bilingual Education-Program } \\
\text { Development and Implementation Grants }\end{array}$ & 1,000 & All or nearly all & Some & $\mathrm{b}$ \\
\hline Education & $\begin{array}{l}\text { Bilingual Education-Program } \\
\text { Enhancement Grants }\end{array}$ & 1,000 & All or nearly all & Some & $\mathrm{b}$ \\
\hline Education & $\begin{array}{l}\text { Bilingual Education-Comprehensive } \\
\text { School Grants }\end{array}$ & 500 & All or nearly all & $\mathrm{b}$ & $\mathrm{b}$ \\
\hline Education & $\begin{array}{l}\text { Bilingual Education-Systemwide } \\
\text { Improvement Grants }\end{array}$ & 1,000 & All or nearly all & $\mathrm{b}$ & $\mathrm{b}$ \\
\hline Education & Ready-To-Learn Television & Don't knowe & Most & $\mathrm{b}$ & b \\
\hline
\end{tabular}


Appendix II

Proportion of Children Receiving Services

From E ducation and Care Programs, by

Target Group

Proportion of children under age 5 receiving

\begin{tabular}{|c|c|c|c|c|c|c|}
\hline $\begin{array}{l}\text { Dental } \\
\text { services }\end{array}$ & $\begin{array}{l}\text { Mental health } \\
\text { services }\end{array}$ & $\begin{array}{l}\text { Speech or } \\
\text { hearing } \\
\text { assessments }\end{array}$ & $\begin{array}{l}\text { Disability } \\
\text { screening }\end{array}$ & Social services & $\begin{array}{l}\text { Services to } \\
\text { parents }\end{array}$ & $\begin{array}{l}\text { Nutritional } \\
\text { services }\end{array}$ \\
\hline Few & Few & Some & Some & Some & Most & All or nearly all \\
\hline Few & Few & Some & Some & Some & All or nearly all & Some \\
\hline Some & Some & Some & Some & Some & Some & Some \\
\hline Few & Few & Few & Some & Most & All or nearly all & All or nearly all \\
\hline Don't know & Don't know & Don't know & Don't know & Don't know & All or nearly all & Most \\
\hline Don't know & Don't know & Don't know & Don't know & Don't know & Don't know & Don't know \\
\hline Don't know & Some & Some & Some & Some & Most & Don't know \\
\hline All or nearly all & All or nearly all & All or nearly all & All or nearly all & All or nearly all & All or nearly all & All or nearly all \\
\hline Don't know & Don't know & Don't know & Don't know & Don't know & Don't know & Don't know \\
\hline Few & Few & Few & Few & Few & Most & Most \\
\hline
\end{tabular}

\begin{tabular}{|c|c|c|c|c|c|c|}
\hline b & Don't know & All or nearly all & All or nearly all & Don't know & Don't know & Don't know \\
\hline $\mathrm{b}$ & Don't know & All or nearly all & All or nearly all & Don't know & Don't know & Don't know \\
\hline None & Few & Most & All or nearly all & Some & Most & Few \\
\hline b & b & b & b & Some & All or nearly all & b \\
\hline b & b & b & b & Some & All or nearly all & b \\
\hline b & $\mathrm{b}$ & $\mathrm{b}$ & $\mathrm{b}$ & Some & Most & b \\
\hline $\mathrm{b}$ & $\mathrm{b}$ & $\mathrm{b}$ & $\mathrm{b}$ & Some & Most & $\mathrm{b}$ \\
\hline $\bar{b}$ & $\mathrm{~b}$ & $\mathrm{~b}$ & $\mathrm{~b}$ & $\mathrm{~b}$ & All or nearly all & $\mathrm{b}$ \\
\hline
\end{tabular}


Appendix II

Proportion of Children Receiving Services

From E ducation and Care Programs, by

Target Group

\begin{tabular}{|c|c|c|c|c|c|}
\hline \multirow[b]{2}{*}{ Agency } & \multirow[b]{2}{*}{ Program name } & \multirow{2}{*}{$\begin{array}{l}\text { Estimated number of } \\
\text { children under age } 5 \\
\text { participating }\end{array}$} & \multicolumn{3}{|c|}{ Proportion of children under age 5 receiving } \\
\hline & & & $\begin{array}{l}\text { Early childhood } \\
\text { education }\end{array}$ & Child care & Health services \\
\hline \multicolumn{6}{|l|}{ Migrants } \\
\hline Education & $\begin{array}{l}\text { Migrant Education-Basic State } \\
\text { Grant Program }\end{array}$ & 69,251 & Some & Few & Some \\
\hline Education & Even Start-Migrant Education & 940 & All or nearly all & All or nearly all & Most \\
\hline \multicolumn{6}{|l|}{ Immigrants } \\
\hline Education & Immigrant Education & Don't know & Don't know & Don't know & $\mathrm{b}$ \\
\hline \multicolumn{6}{|c|}{$\begin{array}{l}\text { Substance-abusing } \\
\text { women with children }\end{array}$} \\
\hline HHS & $\begin{array}{l}\text { Demonstration Grants for } \\
\text { Residential Treatment for } \\
\text { Women and Their Children }\end{array}$ & 235 & All or nearly all & All or nearly all & All or nearly all \\
\hline $\mathrm{HHS}$ & $\begin{array}{l}\text { Grants for Residential } \\
\text { Treatment Programs for } \\
\text { Pregnant and Postpartum } \\
\text { Women }\end{array}$ & 102 & All or nearly all & All or nearly all & All or nearly all \\
\hline \multicolumn{6}{|c|}{ Native populations } \\
\hline \multicolumn{6}{|c|}{$\begin{array}{l}\text { Native American } \\
\text { Indians }\end{array}$} \\
\hline Interior & $\begin{array}{l}\text { Indian Child and Family } \\
\text { Education (FACE) }\end{array}$ & 1,800 & All or nearly all & $\mathrm{b}$ & $\mathrm{b}$ \\
\hline Education & $\begin{array}{l}\text { Indian Education-Grants to } \\
\text { Local Educational Agencies }\end{array}$ & 2,000 & Few & None & Few \\
\hline Education & $\begin{array}{l}\text { Demonstration Grants for } \\
\text { Indian Children }\end{array}$ & 150 & Some & Some & Some \\
\hline Education & $\begin{array}{l}\text { Even Start-Indian Tribes and } \\
\text { Tribal Children }\end{array}$ & 240 & All or nearly all & Most & Most \\
\hline \multicolumn{6}{|c|}{ Native Hawaiians } \\
\hline Education & $\begin{array}{l}\text { Native Hawaiian Family-Based } \\
\text { Education Centers }\end{array}$ & 2,100 & Most & Don't know & None \\
\hline \multicolumn{6}{|c|}{ Alaska Natives } \\
\hline Education & $\begin{array}{l}\text { Alaska Native Home-Based } \\
\text { Education for Preschool } \\
\text { Children }\end{array}$ & 120 & All or nearly all & Don't know & None \\
\hline
\end{tabular}


Appendix II

Proportion of Children Receiving Services

From E ducation and Care Programs, by

Target Group

\section{Proportion of children under age 5 receiving}

\begin{tabular}{|c|c|c|c|c|c|c|}
\hline Dental services & $\begin{array}{l}\text { Mental health } \\
\text { services }\end{array}$ & $\begin{array}{l}\text { Speech or } \\
\text { hearing } \\
\text { assessments }\end{array}$ & $\begin{array}{l}\text { Disability } \\
\text { screening }\end{array}$ & Social services & $\begin{array}{l}\text { Services to } \\
\text { parents }\end{array}$ & $\begin{array}{l}\text { Nutritional } \\
\text { services }\end{array}$ \\
\hline Few & Few & Few & Few & About half & Some & Few \\
\hline All or nearly all & Few & All or nearly all & All or nearly all & All or nearly all & All or nearly all & All or nearly all \\
\hline $\mathrm{b}$ & b & Don't know & Don't know & $\mathrm{b}$ & Don't know & $\mathrm{b}$ \\
\hline
\end{tabular}

\begin{tabular}{llllll}
\hline Some & Most & Most & All or nearly all & All or nearly all & All or nearly all \\
\hline Some & Most & Most & All or nearly all & All or nearly all & All or nearly all
\end{tabular}

\begin{tabular}{|c|c|c|c|c|c|c|}
\hline $\mathrm{b}$ & b & All or nearly all & All or nearly all & $\mathrm{b}$ & All or nearly all & All or nearly all \\
\hline Few & Few & Few & Few & Few & Few & Few \\
\hline Some & Few & Few & Few & Few & Some & Some \\
\hline Some & Some & Some & Some & All or nearly all & All or nearly all & All or nearly all \\
\hline None & Don't know & Don't know & Don't know & Don't know & All or nearly all & Don't know \\
\hline None & Don't know & Some & Some & Don't know & All or nearly all & Don't know \\
\hline
\end{tabular}

${ }^{a}$ We did not compute a total because children may have participated in more than one of the programs listed. For example, a 3-year-old with a disability may have received services under Education's Special Education-Preschool Grants as well as under its Special Education-Grants to States program.

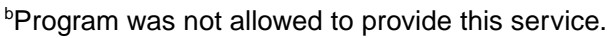

${ }^{\mathrm{c}}$ This number is based on monthly enrollment. 
Appendix II

Proportion of Children Receiving Services

From E ducation and Care Programs, by

Target Group

${ }^{\mathrm{d}}$ Agency officials do not collect participation data for children under age 5 . The reported estimate includes all children receiving day care, a high proportion of whom are assumed to be under age 5 .

eThe agency reported that $4,827,540$ children ages 3 to 8 participated in the program in fiscal year 1999 , but was not able to provide an estimate for the number of children under 5 that participated in the program. 


\section{Comments From the Department of Education}

\section{UNITED STATES DEPARTMENT OF EDUCATION}

OFFICE OF ELEMENTARY AND SECONDARY EDUCATION

THE ASSISTANT SECRETARY

Ms. Cynthia Fagnoni

Director

Education, Workforce, and

APR 202000

Income Security Issues

U.S. General Accounting Office

Washington, DC 20548

Dear Ms. Fagnoni:

This is in response to your letter dated April 10, 2000 to Secretary Richard W. Riley that requests the Department of Education's comments on the draft report, Early Education and Care: Overlap Indicates Need to Assess Crosscutting Programs (GAO/HEHS-00-78). Thank you for the opportunity to provide comments.

The report presents a comprehensive overview of Federal programs providing early education and care for children under the age of five. Some of the programs included have broad authority, and early education and care is only one allowable activity that grantees have the flexibility to provide. Many of the programs also have coordination and integration requirements in the authorizing legislation that promote efficiency. Overall, although the Government Accounting Office correctly points out that some of the programs have overlapping purposes and target populations, it does not provide data to support a conclusion that the overlap results in fragmentation, or redundancy. It would be appropriate if the report made this point explicitly.

In addition to the above comment, we have enclosed a marked-up version of the report with minor edits and technical corrections. We have also enclosed, as promised during the exit conference, some examples of programs that integrate and coordinate services for young children and their families. If I can be of any further assistance, please don't hesitate to contact me at (202) 401-0113.

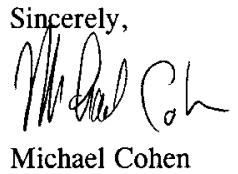

Enclosures 


\section{Comments From the Department of Health and Human Services}

Ms.Cynthia Fagnoni

Director, Education, Workforce,

and Income security Issues

United States General

Accounting office

Washington, D.C. 20548

Dear Ms. Fagnoni:

Enclosed are the Department's comments on your draft report, "Early Education and Care: Overlap Indicates Need to Assess Crosscutting Programs." The comments represent the tentative position of the Department and are subject to reevaluation when the final version of this report is received.

The Department also provided extensive technical comments directly to your staff.

The Department appreciates the opportunity to comment on this draft report before its publication.

Sincerely,

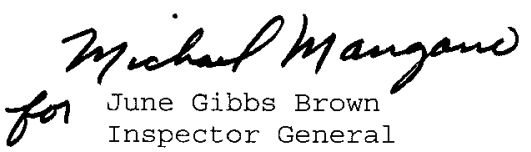

Enclosure

The Office of Inspector General (OIG) is transmitting the

Department's response to this draft report in our capacity as

the Department's designated focal point and coordinator for

General Accounting office reports. The oIG has not conducted

an independent assessment of these comments and therefore

expresses no opinion on them. 


\author{
Appendix IV \\ Comments From the Department of Health \\ and Human Services
}

COMMENTS OF THE DEPARTMENT OF HEALTH AND HUMAN SERVICES ON THE U.S.
GENERAL ACCOUNTING OFFICE'S DRAFT REPORT, "EARLY EDUCATION AND CARE:
OVERLAP INDICATES NEED TO ASSESS CROSSCUTTING PROGRAMS" (GAO/HEHS-00-78)

The Department appreciates the opportunity to review and comment on the above-captioned report. The report provides a useful conceptual framework for thinking about the services that are available to young children and their families. In particular, we are encouraged that the report supports the use of information required by the Government Performance and Results Act to provide answers to some of the questions raised about service effectiveness. However, we are concerned that GAO's report draws conclusions about mission fragmentation and program overlap that are not supported by the findings of the report. In fact, the report acknowledges that more information is needed in order to assess whether programs are effective at achieving their program goals. We believe that before conclusions can be made about fragmentation and duplication in these programs, further analysis would need to be conducted on achievement of each program's goals. The Department's Administration for Children and Families (ACF) is very proud of the advances that have been made in providing early education and care services. We note especially the consolidation of multiple child care funding streams under the Child Care and Development Fund (CCDF) and the high priority that has been placed on full-day, full-year Head Start services-all toward improving the lot of less advantaged families.

\title{
General Comments
}

Child Care and Development Fund. With regard to the programs administered through the Department, we believe it is important to note that the CCDF, created under the Personal Responsibility and Work Opportunity Reconciliation Act (PRWORA) of 1996, was a major step forward in allowing for a more integrated approach to the administration of child care assistance for low income working families. Under PRWORA, welfare-related child care programs, including Job Opportunities and Basic Skills, Transitional, and At-Risk, were combined in a single block grant subject to the provisions of the Child Care and Development Block Grant (CCDBG) Act. This brought these funding streams under a single set of regulations and eased the burden on States, Territories, and Tribes wishing to operate a single subsidy program across family eligibility categories. In addition, by allowing grantees to transfer up to 30 percent of Temporary

Assistance for Needy Families (TANF) dollars into the CCDF, grantees are encouraged to operate a single child care program as opposed to separate TANF and CCDF child care programs.

Collaboration. As was noted in October 26, 1999 comments by the Assistant Secretary for Children and Families in response to an earlier GAO report, "Education and Care: Early Childhood Programs and Services for Low Income Families," Head Start and CCDF are complementary in mission and design, and ACF recognizes the importance of coordination and collaboration between these programs to ensure that the needs of children and families are met This is especially important as more and more Head Start parents are in the labor force and have child care needs that are not met by part-day, part-year Head Start programs. The ACF has made an ongoing commitment to focusing all Head Start expansion efforts on serving children in program models that meet the needs of working low income families.

As delineated in ACF's October response, ACF's Child Care and Head Start Bureaus are actively 


\author{
Appendix IV \\ Comments From the Department of Health \\ and Human Services
}

engaged in a number of collaborative efforts, including a training and technical assistance initiative, "Quality in Linking Together: Early Education Partnerships" (QUILT). The QUILT is working with States toward developing strategic approaches that support and foster early education partnerships at the local level. Together, the Child Care and Head Start Bureaus have sponsored workshops and leadership forums designed to support State and local collaboration, including a Head Start/Child Care/Pre-Kindergarten meeting in October 1999 that involved teams from 21 States. In addition, the Bureaus have joined in providing written technical assistance to grantees on ways to collaboratively blend funds for full-day, full-year services and to correct misinterpretations of rules that may be barriers to partnerships.

The Child Care Bureau has provided guidance to reinforce State flexibility in establishing eligibility periods and to prevent unwarranted problems in audits of agencies that use funding from different Federal programs. The Child Care Bureau has also adopted regulations that require States to describe their efforts to coordinate child care with education, TANF, public health, Head Start, and a number of other programs in their biennial child care plans.

The Head Start Bureau has instituted a number of initiatives among relevant agencies to facilitate collaboration and thus avoid fragmentation and overlap of early childhood and care programs. Examples of such initiatives include:

- The most recent Program Instruction to Head Start Grantees and Delegate Agencies entitled, "Head Start Funding Increase for Fiscal Year 2000" (Log \# ACYF-PI-HS-00-02; Issuance Date, $2 / 15 / 00$ ). One of two distinct competitions in this instruction is for the provision of funds to increase the number of children in existing Head Start enroliment slots that are provided fullyear, full-day services designed to meet the needs of working families. In order for Head Start grantees to be funded for this competition, they must present an acceptable plan to: provide full-day, full-year services for Head Start children; ensure a collaborative planning process with community child care and early childhood programs and providers; and utilize available opportunities to combine Head Start funds with significant resources from other early childhood programs or funding streams, including State, local and private sector funding for child care, pre-kindergarten and special education services.

- An Information Memorandum (IM) to Head Start Grantees and Delegate Agencies, "Improving Head Start Collaboration with Programs Funded through the Child Care and Development Block Grant, (Log \#: ACYF-IM-HS-99-10; Issuance Date: 6/29/99). This memorandum supports the development of consistent eligibility periods among Head Start programs and CCDBG-supported programs, in order to eliminate an obstacle to collaboration. A similar memorandum was also sent to CCDF grantees by the Child Care Bureau.

- The Head Start-State Collaboration Offices that have been funded in every State and the District of Columbia and the Commonwealth of Puerto Rico. These programs serve as catalysts for promoting collaboration between Head Start and a wide range of programs across a State (that is, primarily programs that involve coordination of Head Start services with health care, welfare, child care, education and community service activities, family literacy activities, activities relating to children with disabilities, and services for homeless children). A draft descriptive study of the collaboration offices by 
Appendix IV

Comments From the Department of Health

and Human Services

an independent contractor points to their overall success in the formation or enhancement of numerous partnerships with health and welfare, child care and education agencies.

The ACF's Head Start/Child Care work group includes membership from both the Head Start and Child Care Bureaus, as well as from ACF's regional offices. The work group meets periodically to discuss methods to facilitate collaboration among Head Start and child care programs.

In addition, there are considerable efforts across ACF to coordinate and collaborate relative to child care. For example, the Office of Family Assistance (OFA), which administers TANF, holds regular audio and video conferences across the Nation which include a focus on child care topics. In addition, child care workshops were included in a series of Promising Practices Conferences held over the period of September 1998 to April 1999 in five different cities. Finally, OFA sponsors the Welfare Peer Technical Assistance Network (Network) to facilitate linkages between organizations serving welfare recipients and their partners at the community level. The Network's September 1999 conference, "Building Rural Partnerships," held in St. Paul, Minnesota,

emphasized the importance of developing partnerships with the child care community. 
The first copy of each GAO report is free. Additional copies of reports are $\$ 2$ each. A check or money order should be made out to the Superintendent of Documents. VISA and MasterC ard credit cards are accepted, also.

Orders for 100 or more copies to be mailed to a single address are discounted 25 percent.

Orders by mail:

U.S. General Accounting Office

P.O. Box 37050

Washington, DC 20013

Orders by visiting:

Room 1100

700 4th St. NW (corner of 4th and G Sts. NW)

U.S. General Accounting Office

Washington, DC

Orders by phone:

(202) 512-6000

fax: (202) 512-6061

TDD ( 202) 512-2537

E ach day, GAO issues a list of newly available reports and testimony. To receive facsimile copies of the daily list or any list from the past 30 days, please call (202) 512-6000 using a touchtone phone. A recorded menu will provide information on how to obtain these lists.

Orders by Internet:

For information on how to access GAO reports on the Internet, send an e-mail message with "info" in the body to:

info@www.gao.gov

or visit GAO's World Wide Web home page at:

http://www.gao.gov

To Report Fraud, Waste, or Abuse in Federal Programs

\section{Contact one:}

- Web site: http://www.gao.gov/fraudnet/fraudnet.htm

- e-mail: fraudnet@gao.gov

- 1-800-424-5454 (automated answering system) 

United States

General Accounting Office

Washington, D.C. 20548-0001

Official Business

Penalty for Private Use $\$ \mathbf{3 0 0}$
Bulk Rate

Postage \& F ees Paid GAO

Permit No. GI00 